\title{
Synthesis of microbial protein from ammonia in the sheep's rumen and the proportion of dietary nitrogen converted into microbial nitrogen
}

\author{
By A. F. PILGRIM, F. V. GRAY, R. A. WELLER \\ AND C. B. BELLING \\ Division of Nutritional Biochemistry, CSIRO, Adelaide, South Australia
}

(Received 20 November 1969-Accepted 29 December 1969)

\begin{abstract}
I. The extent to which ammonia- $\mathrm{N}\left(\mathrm{NH}_{3}-\mathrm{N}\right)$ serves as a starting point for synthesis of microbial nitrogenous compounds was assessed when ${ }^{15} \mathrm{~N}$ as $\left({ }^{15} \mathrm{NH}_{4}\right)_{2} \mathrm{SO}_{4}$ was continuously infused into the rumen of a sheep for periods of $78-98 \mathrm{~h}$. Steady states were reached in the composition of the rumen contents because the animal was fed equal parts of its ration at hourly intervals. Concentrations of ${ }^{15} \mathrm{~N}$ in bacterial- $\mathrm{N}$, protozoal- $\mathrm{N}$ and rumen $\mathrm{NH}_{3}-\mathrm{N}$ were compared.

2. In two trials with a low- $\mathrm{N}$ diet consisting largely of wheaten hay the ${ }^{15} \mathrm{~N}$ concentration in bacterial $\mathrm{N}$ was 76 and $78 \%$ of that in the $\mathrm{NH}_{3}-\mathrm{N}$. For protozoa the values were more variable -64 and $43 \%$.

In two trials with a higher-N diet (lucerne hay), the corresponding values were lowerbacterial-N 62 and $64 \%$, protozoal- $\mathrm{N}_{4} \mathrm{I}$ and $35 \%$. It was concluded that synthesis of microbial protein was more dependent on ammonia as a starting point with the low-N diet than with the higher- $\mathrm{N}$ diet.

3. Entry and exit rates for ammonia into and out of the rumen system were determined, and the results, in combination with those obtained for bacterial- $\mathrm{N}$ in the first part of the work, allowed calculations to be made of the production of microbial- $\mathrm{N} / \mathrm{d}$ formed from $\mathrm{NH}_{\mathbf{3}}-\mathrm{N}$, and this in turn allowed calculation of minimal values for conversion of plant- $\mathrm{N}$ to microbial- $\mathrm{N}$ in the rumen. Minimal extent of conversion was $68 \%$ for the low-N diet and $53-55 \%$ for the higher- $\mathrm{N}$ diet.

4. Total production of microbial- $\mathrm{N}$ in relation to the amount of $\mathrm{N}$ given was also calculated by using previously reported values for the relative proportions of protozoal-N and bacterial- $N$ in sheep given diets similar to those used here. These values for extent of conversion were $73 \%$ for the low-N diet and $5^{8-59} \%$ for the higher-N diet.
\end{abstract}

It has been established that ruminants can be maintained on diets containing no protein but only a non-protein source of nitrogen such as urea or various ammonium salts (Loosli, Williams, Thomas, Ferris \& Maynard, I949; Duncan, Agrawala, Huffman \& Luecke, I953; Virtanen, 1966). Under these conditions it seems unlikely that the flora and fauna of the rumen could remain unchanged from those found in animals given normal diets containing protein, and it has been demonstrated (Bryant \& Robinson, 1963 ; Borchers, 1967 ) that while many rumen bacteria are capable of using ammonia as sole $\mathrm{N}$ source, others appear to need or prefer preformed amino acids. The degrees to which ammonia, amino acids or even peptides may constitute starting points for synthesis of microbial-N in normally fed ruminants have not been ascertained, but could be expected to vary with the nature of the diet and possibly with the particular animals under observation. Some evidence is already available to suggest that in normal feeding (e.g. hay-fed cattle and sheep), ammonia- $\mathrm{N}\left(\mathrm{NH}_{3}-\mathrm{N}\right)$ may be the starting point to a very considerable extent (Portugal \& Sutherland, ig66).

The experiments described here were based on the uptake by rumen micro- 
organisms of ${ }^{15} \mathrm{~N}$ from $\left({ }^{15} \mathrm{NH}_{4}\right)_{2} \mathrm{SO}_{4}$ infused into the rumen. For two diets of different $\mathrm{N}$ content fed to the same sheep the amount of microbial-N shown to be derived from $\mathrm{NH}_{3}-\mathrm{N}$ was between 62 and $78 \%$ of the total. Additional calculations, based on measured entry rates of $\mathrm{NH}_{3}-\mathrm{N}$ into the rumen showed that minimal values for conversion of dietary- $\mathrm{N}$ into microbial- $\mathrm{N}$ ranged from 53 to $68 \%$.

\section{EXPERIMENTAL}

\section{General}

The procedure adopted included constant infusion of $\left({ }^{15} \mathrm{NH}_{4}\right)_{2} \mathrm{SO}_{4}$ into the rumen of a sheep fed on equal parts of its daily ration at intervals of $\mathrm{r} h$. In this way a close approach to a steady composition of the rumen contents, including the concentration of ammonia and of its ${ }^{15} \mathrm{~N}$ content, was obtained after a period of $2 \mathrm{~d}$ or more. Bacteria and protozoa were separated from samples of the rumen material and analysed for their content of ${ }^{15} \mathrm{~N}$. These were then compared with that of the ammonia in the rumen. A second part of the work included determination of $\mathrm{NH}_{3}-\mathrm{N}$ and VFA entry rates into the rumen.

\section{Feeding}

Only one sheep was used throughout the trials-a Merino ewe of approx. $40 \mathrm{~kg}$. The diets were lucerne hay, and a mixture of wheaten hay $(75 \%)$ with lucerne hay $(25 \%)$. Each diet was given as chaff in a daily ration of $800 \mathrm{~g}$, presented by an automatic feeder (Gray, Weller, Pilgrim \& Jones, I967) in equal lots at $\mathrm{I} h$ intervals throughout each $24 \mathrm{~h}$.

\section{Infusions into the rumen}

Continuous infusion of $\left({ }^{15} \mathrm{NH}_{4}\right)_{2} \mathrm{SO}_{4}$ was carried out for periods of up to $98 \mathrm{~h}$ by a peristaltic-type pump at a constant rate for each trial. Concentration of ${ }^{15} \mathrm{~N}$ in the solution was approx. $0.2 \mathrm{~g} / \mathrm{l}$ and the infusion rate was about $500 \mathrm{ml} / \mathrm{d}$.

In some experiments polyethylene glycol $(\mathrm{PEG})$ and $\left[\mathrm{I}^{14} \mathrm{C}\right]$ sodium acetate were included in the infusion solution for determination of production and absorption rates of ammonia and of volatile fatty acid (VFA) (Pilgrim, Gray \& Belling, 1969). Concentrations used were approx. $3^{\circ} \mathrm{g}$ PEG and $30 \mu \mathrm{c}{ }^{14} \mathrm{C} / 1$ of the infusion solution.

\section{Sampling rumen fluid for determination of ${ }^{15} N$ in ammonia}

In the first trial individual samples of rumen fluid were taken at the same times as the samples of whole rumen contents used for separation of the micro-organisms. In the later experiments continuous automatic sampling of the fluid (Weller, Gray, Pilgrim \& Jones, I967) was adopted so that a composite sample was available each $24 \mathrm{~h}$ for ammonia determinations, and also for the determinations of PEG and of ${ }^{14} \mathrm{C}$ in the VFA.

\section{Separation of micro-organisms from rumen contents}

Procedure 1. The sample of rumen contents was squeezed through terylene voile. No precise account was kept of the proportions of solid and liquid in the heterogeneous rumen material but in general about $30 \mathrm{~g}$ of moist solids and $90 \mathrm{ml}$ of squeezed- 
out rumen fluid were present. The moist solids were washed twice with water and squeezed again through the voile. The combined rumen fluid and washings were centrifuged at $170 \mathrm{~g}$ for $\mathrm{I} 5 \mathrm{~s}$ to throw down the protozoa and these were washed twice with water, by which time microscopic examination showed that they were practically free of other material although some traces of contamination were still visible. The combined supernatant liquids were centrifuged at $12000 \mathrm{~g}$ for $30 \mathrm{~min}$ to throw down the bacteria and then the supernatant liquid was discarded.

In trial $\mathrm{I}$ the procedure was also carried out with an additional supersonic treatment (treatment for 2 min by Soniprobe--Type Ir $3 \circ \mathrm{A}$; Daw Instruments Ltd, London $(20 \mathrm{kHz}$ pulsed at $100 \mathrm{~Hz}))$ of the washed solids-resuspending them and proceeding as above.

Procedure 2. Trials 2, 3 and 4 . About $300 \mathrm{ml}$ of rumen fluid were allowed to stand in a tall cylinder for about $20 \mathrm{~min}$ in an incubator at $40^{\circ}$. By then some protozoa and plant material had formed a layer at the bottom while other residues had risen to the top. The fairly clear intermediate layer was removed and centrifuged at $170 \mathrm{~g}$ for I $5 \mathrm{~s}$ to remove the remaining protozoa, which were discarded. The supernatant liquid was centrifuged at $12000 \mathrm{~g}$ for $30 \mathrm{~min}$ to obtain the bacteria. The sample of protozoa was obtained separately as in procedure $\mathrm{I}$.

Analytical methods. $\mathrm{N}$ was determined by the Kjeldahl method and ${ }^{15} \mathrm{~N}$ in ammonia as previously described (Pilgrim et al. 1969 ). For ${ }^{15} \mathrm{~N}$ in the bacteria and protozoa, ammonia was distilled from Kjeldahl digests made alkaline with $\mathrm{NaOH}$. It was neutralized with $0.05 \mathrm{~N}-\mathrm{H}_{2} \mathrm{SO}_{4}$ and brought to dryness for ${ }^{15} \mathrm{~N}$ determination in the mass spectrometer.

VFA and ${ }^{14} \mathrm{C}$ in VFA were determined as previously reported (Weller et al. 1967 ) and PEG by the turbidimetric method of Hydén (1955).

\section{RESULTS}

The place of ammonia in the synthesis of microbial nitrogenous compounds

Mixed roughage diet : trial $\mathrm{I}$. The first experiment lasted $78 \mathrm{~h}$. Samples of rumen contents for separation of micro-organisms and samples of rumen fluid for determination of $\mathrm{NH}_{3}-\mathrm{N}$ were taken at times shown in Fig. I $a$. Concentrations of ${ }^{15} \mathrm{~N}$ excess in bacterial$\mathrm{N}$ and protozoal- $\mathrm{N}$, expressed as a percentage of the corresponding ${ }^{15} \mathrm{~N}$ in rumen $\mathrm{NH}_{3}-\mathrm{N}$ were calculated from these values and are shown in Fig. $\mathrm{I} b$. It is evident that a fairly steady state in regard to the concentration of ${ }^{15} \mathrm{~N}$ excess in rumen $\mathrm{NH}_{3}-\mathrm{N}$ developed between 48 and $78 \mathrm{~h}$ and that the excess ${ }^{15} \mathrm{~N}$ concentrations in the micro-organisms were at least approaching steady values by $78 \mathrm{~h}$. For these two types of organism respectively the values were 78 and $64 \%$ of the concentration of excess ${ }^{15} \mathrm{~N}$ in the rumen $\mathrm{NH}_{3}-\mathrm{N}$.

Trial 2 (mixed roughages, duration extended to $98 \mathrm{~h}$ ). In this as in later trials $\mathrm{NH}_{3}-\mathrm{N}$ was determined in each day's composite sample of rumen fluid rather than only at the times when the micro-organisms were sampled. The results are plotted in Fig. 2 in the same way as for trial $\mathrm{r}$. The concentration of ${ }^{15} \mathrm{~N}$ excess in bacterial $\mathrm{N}$ at $98 \mathrm{~h}$ was $78 \%$ of that in the $\mathrm{NH}_{3}-\mathrm{N}$, a value close to that found in trial $\mathrm{I}$, despite differences in 
procedure for sample preparation. For the protozoa, however, the proportion was only $43 \%$ as against $64 \%$ for the previous trial.

Lucerne hay diet: trials 3 and 4 . Each of these trials lasted $98 \mathrm{~h}$ and the same general pattern of changes took place as with the lower- $\mathrm{N}$ diet of mixed roughages. But the
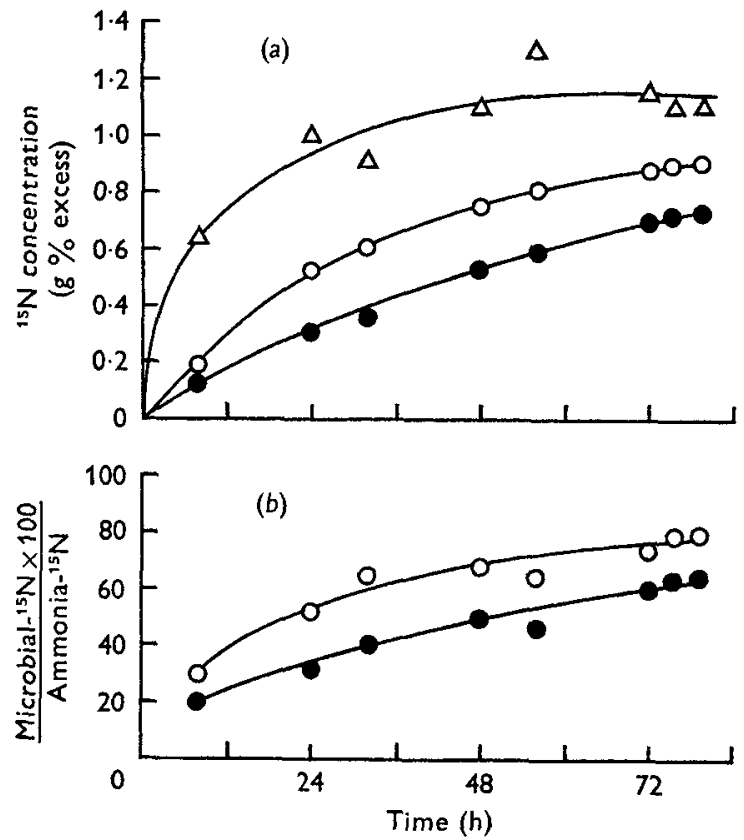

Fig. I. ${ }^{15} \mathrm{~N}$ in $\mathrm{NH}_{3}-\mathrm{N}$ and microbial- $\mathrm{N}$ under developing steady-state conditions in the sheep's rumen. The diet was $75 \%$ wheaten hay $+25 \%$ lucerne hay.
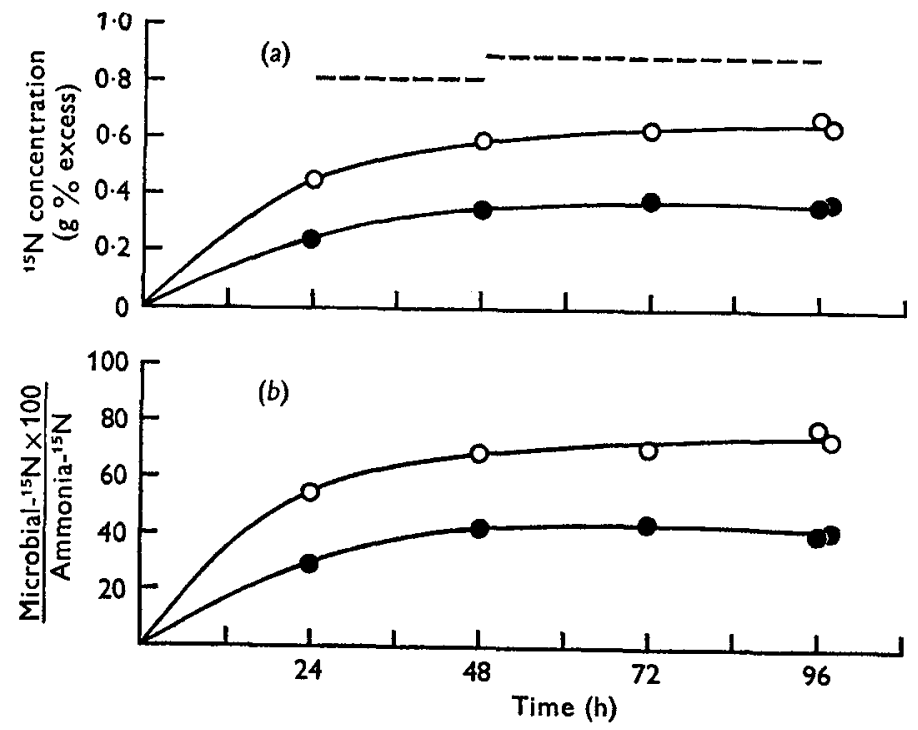

Fig. 2. ${ }^{15} \mathrm{~N}$ in $\mathrm{NH}_{3}-\mathrm{N}$ and microbial- $\mathrm{N}$ under developing steady-state conditions in the sheep's rumen. The diet was $75 \%$ wheaten hay $+25 \%$ lucerne hay, and composite daily samples of
rumen fluid were analysed. 
results, presented in Fig. 3, indicated that ammonia played a lesser part as a starting point in the synthesis of microbial nitrogenous compounds.

Results from all the trials are summarized in Table $\mathbf{I}$.

Table I. The extent to which microbial- $N$ was calculated to be derived from $\mathrm{NH}_{3}-\mathrm{N}$ in the rumen of the sheep

\begin{tabular}{|c|c|c|c|c|c|c|c|}
\hline \multirow[b]{2}{*}{$\begin{array}{l}\text { Trial } \\
\text { no. }\end{array}$} & \multirow[b]{2}{*}{ Diet } & \multirow{2}{*}{$\begin{array}{l}N \text { in } 800 \mathrm{~g} \\
\text { ration } \\
(\mathrm{g})\end{array}$} & \multicolumn{3}{|c|}{$\begin{array}{l}{ }^{15} \mathrm{~N} \text { at end of trial } \\
\text { (atoms \% excess) }\end{array}$} & \multicolumn{2}{|c|}{$\begin{array}{l}{ }^{15} \mathrm{~N} \text { in microbial-N } \\
\text { as a proportion of } \\
{ }^{15} \mathrm{~N} \text { in } \mathrm{NH}_{3}-\mathrm{N}\end{array}$} \\
\hline & & & & Bacterial-N & Protozoal-N & $\begin{array}{l}\text { Bacteria } \\
(\%)\end{array}$ & $\begin{array}{c}\text { Protozoa } \\
(\%)\end{array}$ \\
\hline $\begin{array}{l}1 \\
2\end{array}$ & $\begin{array}{l}75 \% \text { Wheaten hay } \\
+25 \% \text { lucerne hay }\end{array}$ & $\begin{array}{l}12 \cdot 5 \\
12 \cdot 5\end{array}$ & $\begin{array}{l}1 \cdot 13 \\
0.88\end{array}$ & $\begin{array}{l}0.88 \\
0.67\end{array}$ & $\begin{array}{l}0 \cdot 72 \\
0.38\end{array}$ & $\begin{array}{l}78 \\
76\end{array}$ & $\begin{array}{l}64 \\
43\end{array}$ \\
\hline $\begin{array}{l}3 \\
4\end{array}$ & I00\% Lucerne hay & $\begin{array}{l}22 \cdot 9 \\
22 \cdot 9\end{array}$ & $\begin{array}{l}0.68 \\
0.74\end{array}$ & $\begin{array}{l}0.44 \\
0.46\end{array}$ & $\begin{array}{l}0.28 \\
0.26\end{array}$ & $\begin{array}{l}64 \\
62\end{array}$ & $\begin{array}{l}4 \mathrm{I} \\
35\end{array}$ \\
\hline
\end{tabular}
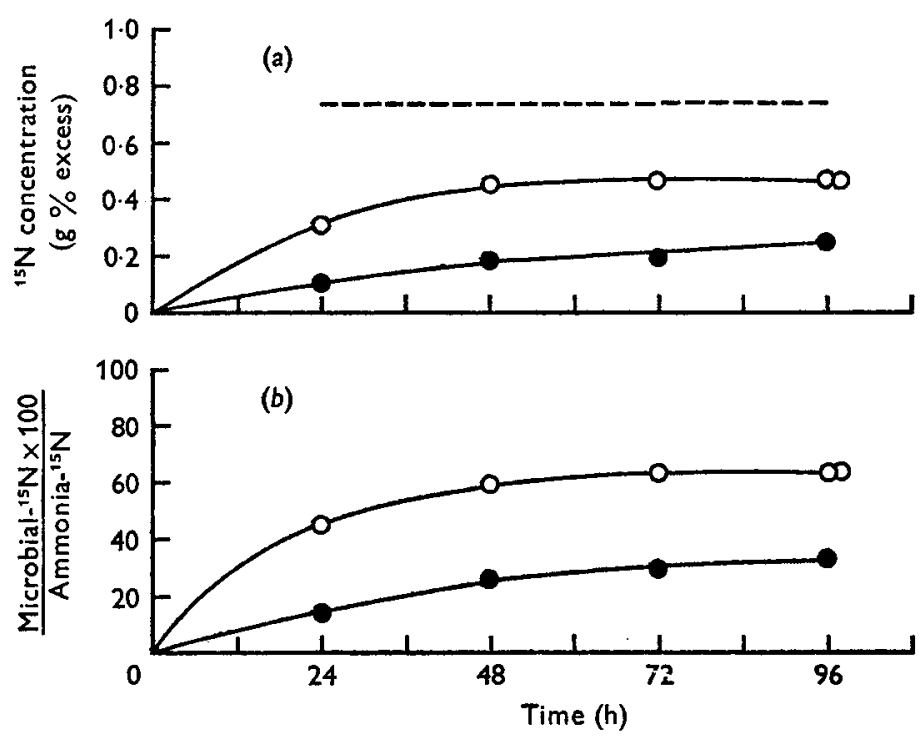

Fig. ${ }^{16}{ }^{16} \mathrm{~N}$ in $\mathrm{NH}_{3}-\mathrm{N}$ and microbial-N under developing steady-state conditions in the sheep's rumen. The diet was lucerne hay, and composite daily samples of rumen fluid were analysed.

\section{The proportion of dietary- $N$ converted into microbial- $N$}

Entry rates for ammonia into the rumen were determined in three of the trials through measurement of dilution of ${ }^{15} \mathrm{~N}$ infused in $\left({ }^{15} \mathrm{NH}_{4}\right)_{2} \mathrm{SO}_{4}$ in a way similar to that used for the determination of entry rates for VFA (Weller et al. 1967). For example, in trial 3 , by the time a steady state had been set up in the rumen $0.119 \mathrm{~g}{ }^{15} \mathrm{~N}$ was being infused each day and the concentration of ${ }^{15} \mathrm{~N}$ in the $\mathrm{NH}_{3}-\mathrm{N}$ in the rumen was 0.68 atoms $\%$ excess. Therefore entry and exit rate for $\mathrm{NH}_{3}-\mathrm{N}$ was $0.119 / 0.0068=$ $17.5 \mathrm{~g} / \mathrm{d}$. (Entry included $\mathrm{N}$ from the diet and from recycled urea; exit included adsorption from the rumen, passage to the omasum and incorporation into compounds other than ammonia.) 
Now at the same time the VFA entry and exit rates were found by isotope dilution of ${ }^{14} \mathrm{C}$ to be $4 \cdot 14$ moles VFA/d. The mean concentrations of $\mathrm{NH}_{3}-\mathrm{N}$ and VFA in the rumen fluid were $0.193 \mathrm{~g} / 1$ and 0.84 moles/1 respectively. Since it has been shown that the rate constants for removal of ammonia and VFA from the rumen are approximately equal in the conditions of the present experiment (Pilgrim et al. 1969) it can be calculated that the amount of $\mathrm{N}$ absorbed as ammonia through the rumen wall or further along the alimentary tract was

$$
\frac{4^{.14} \times 0.193}{0.84}=9.5 \mathrm{~g} \mathrm{~N} / \mathrm{d} \text {. }
$$

The total $\mathrm{NH}_{3}-\mathrm{N}$ entering the system $(17.5 \mathrm{~g} \mathrm{~N} / \mathrm{d})$ was either removed as $\mathrm{NH}_{3}$ or finally incorporated into microbial- $\mathrm{N}$, with the exception of small quantities of other nitrogenous compounds remaining in the rumen fluid. Microbial-N formation through ammonia was therefore close to $17 \cdot 5-9 \cdot 5=8 \cdot 0 \mathrm{~g} \mathrm{~N} / \mathrm{d}$. If we take the observed fact that not more than $64 \%$ of the microbial- $\mathrm{N}$ was formed from $\mathrm{NH}_{3}-\mathrm{N}$ as a starting point (Table I) we can arrive at a minimal value for the amount of dietary- $\mathrm{N}$ converted into microbial-N. On this basis the $8.0 \mathrm{~g} \mathrm{~N} / \mathrm{d}$ of microbial $\mathrm{N}$ formed through, ammonia as starting point represented a microbial-N formation of at least $12.5 \mathrm{~g} / \mathrm{d}$, equivalent to $55 \%$ of the dietary- $\mathrm{N}$. This is a minimal value since some of the microbial-N was protozoal-N and only $4 \mathrm{I} \%$ of this was found to be derived from ammonia. The full value for microbial-N production could be determined only if the relative proportions of bacterial and protozoal-N in the rumen were known.

Table 2. The calculation of minimal values for the conversion of dietary $N$ into microbial $N$ in the rumen of the sheep

\begin{tabular}{|c|c|c|c|c|c|c|c|}
\hline \multirow[b]{2}{*}{$\begin{array}{l}\text { Trial } \\
\text { no. }\end{array}$} & \multirow[b]{2}{*}{ Diet } & \multirow[b]{2}{*}{$\begin{array}{l}N \text { fed } \\
(g / 24 h)\end{array}$} & \multicolumn{3}{|c|}{$\mathrm{NH}_{3}-\mathrm{N}$ in rumen } & \multicolumn{2}{|c|}{$\begin{array}{l}\text { Microbial-N produced } \\
\text { (minimal) }\end{array}$} \\
\hline & & & $\begin{array}{c}\text { Entry } \\
(\mathrm{g} / 24 \mathrm{~h})\end{array}$ & $\begin{array}{c}\text { Absorbed } \\
\text { as } \mathrm{NH}_{3}-\mathrm{N} \\
(\mathrm{g} / 24 \mathrm{~h})\end{array}$ & $\begin{array}{l}\text { Incorpo- } \\
\text { rated in } \\
\text { microbial-N } \\
(\mathrm{g} / 24 \mathrm{~h})\end{array}$ & $\mathrm{g} / 24 \mathrm{~h}$ & $\begin{array}{c}\text { Proportion } \\
\text { of dietary } \\
N(\%)\end{array}$ \\
\hline 2 & $\begin{array}{l}\text { Wheaten hay } \\
\text { +lucerne hay }\end{array}$ & $12 \cdot 5$ & $12 \cdot 2$ & 5.6 & 6.6 & $8 \cdot 5$ & 68 \\
\hline $\begin{array}{l}3 \\
4\end{array}$ & Lucerne hay & $\begin{array}{l}22 \cdot 9 \\
22 \cdot 9\end{array}$ & $\begin{array}{l}17.5 \\
15.9\end{array}$ & $\begin{array}{l}9 \cdot 5 \\
8 \cdot 4\end{array}$ & $\begin{array}{l}8 \cdot 0 \\
7 \cdot 5\end{array}$ & $\begin{array}{l}12.5 \\
12.1\end{array}$ & $\begin{array}{l}55 \\
53\end{array}$ \\
\hline
\end{tabular}

The work reported by Pilgrim et al. (1969) referred only to a lucerne hay diet. Later, repetition with the mixture of roughages used in the present experiments led to the same conclusion (Pilgrim \& Belling, r969, unpublished) and so the type of calculation employed here is justified for both' diets. A summary of the findings for the three trials in which these calculations were made is given in Table 2.

\section{DISCUSSION}

It is to be expected that different sheep may have somewhat different populations of bacteria in the rumen and could therefore depend to a greater or lesser degree on ammonia as a starting point for microbial protein synthesis from any given diet. In particular, differences might be expected to depend very much on the amount and 
type of protein in the diet. The work presented here must be considered to be of a preliminary and exploratory nature. For this reason, and because of the restricted amount of ${ }^{15} \mathrm{~N}$ available to us for long periods of continuous infusion, we preferred to deal with only one animal in our attempt to see how far the synthesis depended on ammonia when two diets of different protein content were presented to it.

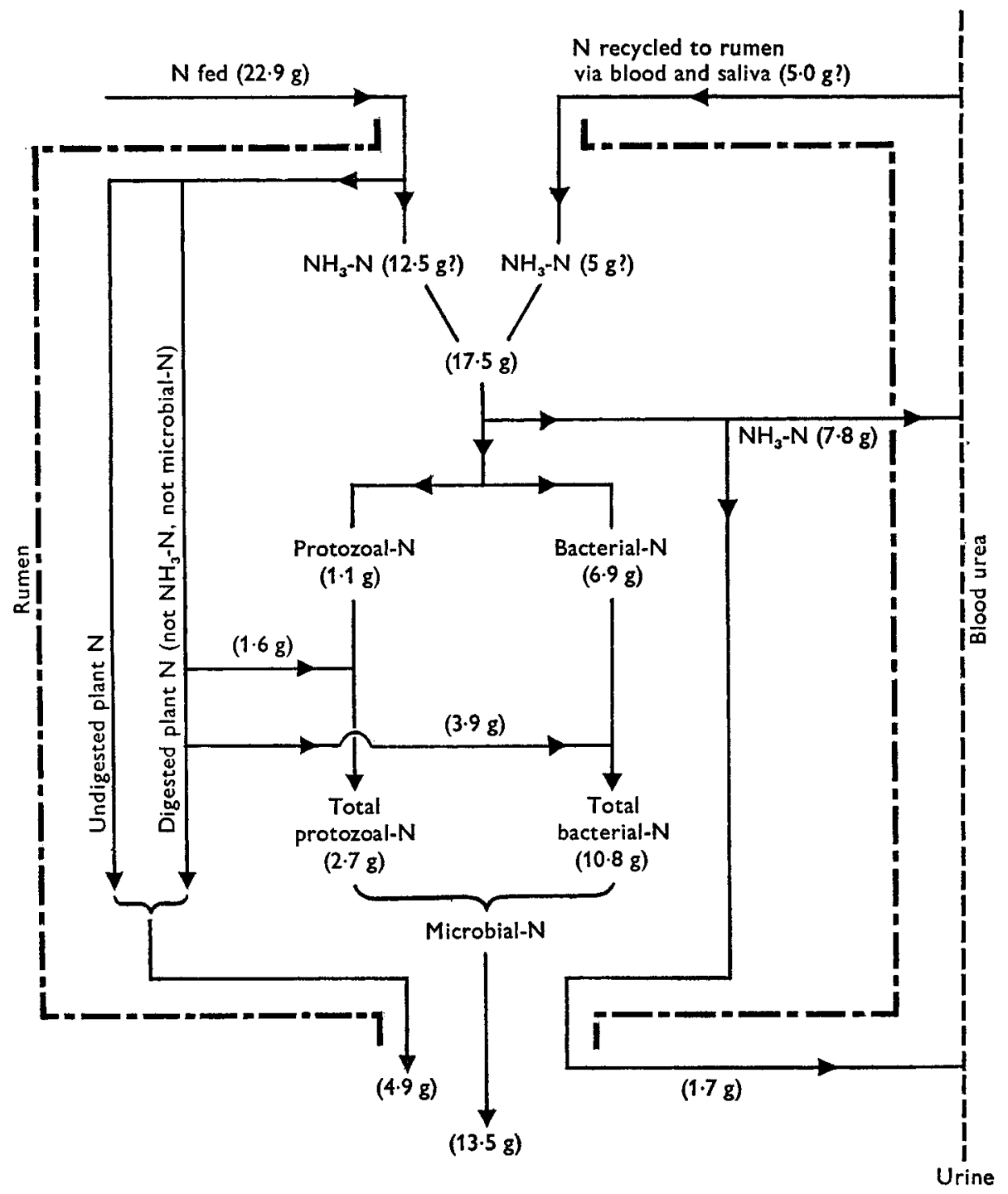

Fig. 4. Diagram of progress of nitrogen through the sheep's rumen. (Values in parentheses are based on values from trial 3 . The assumption of $5^{\circ} \mathrm{Og}$ recycled $\mathrm{N}$ does not affect other values quoted except that if it were less, then a correspondingly greater value would be given to $\mathrm{NH}_{3}-\mathrm{N}$ formed from plant $\mathrm{N}$ to make up the measured total of $\mathrm{I}_{7} \cdot 5 \mathrm{~g}$ formed.)

An assumption made in the planning of the work was that there would be no significant exchange of $\mathrm{N}$ atoms between ammonia and amino-acids or peptides in the rumen fluid without the intervention of micro-organisms. 
On the basis of this assumption it can be said that with the diet relatively low in $\mathrm{N}$ (mixed roughages) the sheep was very dependent on ammonia as a starting point for synthesis of microbial nitrogenous compounds; ammonia formed from the diet, and that recycled to the rumen via urea, was evidently an intermediate in the formation of nearly $80 \%$ of the bacterial-N. But with the higher-N diet of lucerne hay this dependence fell to less than $65 \%$.

For microbial-N production in the rumen a similar difference was found. When $68 \%$ of the dietary $\mathrm{N}$ was converted from the low $\mathrm{N}$ diet the corresponding value for lucerne hay was $53-55 \%$. It has been stated that these are minimal values. If we accept the mean proportions of bacterial- and protozoal- $\mathrm{N}$ found for the same diet by Weller, Pilgrim \& Gray (1962), it can be assumed that approx. $20 \%$ of the microbial-N was protozoal-N and $80 \%$ bacterial-N.

Table 3. The total production of microbial- $N$ in relation to the amount of $N$ given in the diet of sheep, calculated from previously reported values for the relative proportions of protozoal- $N$ and bacterial- $N$

\begin{tabular}{|c|c|c|c|}
\hline \multirow{2}{*}{ Trial no. } & \multirow[b]{2}{*}{ Diet } & \multicolumn{2}{|c|}{$\begin{array}{l}\text { Microbial-N production in the rumen } \\
\text { expressed as proportion of dietary } N\end{array}$} \\
\hline & & $\begin{array}{c}\text { Minimal value } \\
\text { from Table } 2 \\
(\%)\end{array}$ & $\begin{array}{l}\text { Full value } \\
(\%)\end{array}$ \\
\hline 2 & Mixed roughages & 68 & 73 \\
\hline $\begin{array}{l}3 \\
4\end{array}$ & \}Lcerne hay & $\begin{array}{l}55 \\
53\end{array}$ & $\begin{array}{l}59 \\
58\end{array}$ \\
\hline
\end{tabular}

In trial 3 with lucerne hay, 8.0 g microbial- $\mathrm{N}$ was formed via $\mathrm{NH}_{3}-\mathrm{N}$ per $\mathrm{d}$. If the total microbial- $\mathrm{N}$ formed was $x \mathrm{~g} / \mathrm{d}$ then ( $\mathrm{I}$ ) $0.8 x \mathrm{~g}$ bacterial- $\mathrm{N}$ was formed and only $64 \%$ of this or $0.512 x \mathrm{~g}$ was produced via $\mathrm{NH}_{3}-\mathrm{N}$, while $0.288 x \mathrm{~g}$ was formed from other sources. (2) Similarly, $0.2 x \mathrm{~g}$ protozoal- $\mathrm{N}$ was formed and $4 \mathrm{I} \%$ of this or $0.082 x \mathrm{~g}$ was produced via $\mathrm{NH}_{3}-\mathrm{N}$ while $0.1 \mathrm{I} 8 x \mathrm{~g}$ were formed from other sources.

Hence $0.512 x+0.082 x=8.0$ and $x=13.5 \mathrm{~g} / \mathrm{d}$. This $13.5 \mathrm{~g}$ of total microbial-N formed represents $59 \%$ of the dietary N. A diagram is given in Fig. 4 to illustrate the progress of $\mathrm{N}$ through the rumen in accordance with these assumptions and calculations. The results for total microbial- $\mathrm{N}$ formation together with the minimal values from Table 2 are shown in Table 3.

The work has shown that in the same sheep the starting point for synthesis of microbial nitrogenous compounds may lie in ammonia to a varying degree according to the amount and perhaps type of protein in the diet. It has shown also that the total production of microbial nitrogenous compounds in relation to the $\mathrm{N}$ fed may vary considerably from diet to diet. It appears that with the lucerne hay used, not very much more than half of the dietary $\mathrm{N}$ passed on as microbial- $\mathrm{N}$; there may have been a relatively small net absorption of ammonia, but probably a significant part passed on as plant $\mathrm{N}$ or other non-microbial material.

The only comparison we can make with our earlier work in this respect is with the 
finding (Weller, Gray \& Pilgrim, 1958) that in sheep fed once a day on wheaten hay, $6 \mathrm{I}-82 \%$ of the $\mathrm{N}$ in the rumen was present as microbial-N and it was considered that the higher rather than the lower value was indicative of the true proportion in material passing to the omasum.

\section{Preparation of bacterial samples-use of the supersonic probe}

One obvious aim in the preparation of bacterial samples was to obtain a representative sample of the whole population. It was thought that use of a supersonic probe to help to shake micro-organisms from the plant fibres would be useful in this respect in view of the fact that a considerable proportion of the bacterial- $\mathrm{N}$ in rumen contents may be fairly closely attached to plant particles (Weller et al. 1958). Comparisons were made with and without use of the probe for the low- $\mathrm{N}$ diet consisting largely of wheaten hay, but no difference in abundance of ${ }^{15} \mathrm{~N}$ in the bacterial-N was found. Lucerne hay samples prepared with use of the probe did show a somewhat lower abundance of ${ }^{15} \mathrm{~N}$ than those prepared without it. Microscopic examination of these latter preparations, however, suggested strongly that many more fine plant particles were being collected along with the bacteria. This led us to abandon use of the probe and instead to accept the fact that our preparation might not be fully representative of the total population.

Although it has been shown that many bacteria are closely held to the plant particles the fact remains that the great bulk of them are carried out of the rumen in the rumen fluid. This is indicated by the observation that, although there may be a relatively even distribution of bacteria between fluid and solids in the rumen contents, the turnover of fluid in the system is much faster than that of the plant solids (see work with lignin and PEG as markers of flow (Weller et al. 1962)). On these grounds as well as those mentioned above, we considered it satisfactory to carry out the last three trials without using the ultrasonic probe.

\section{Incorporation of ${ }^{15} \mathrm{~N}$ into the protozoa}

It is well established that many of the protozoa feed extensively on bacteria (see e.g. Wallis \& Coleman, 1967). Many can be seen to have ingested plant particles but it is doubtful to what extent digestion of these particles is first carried out by the bacteria associated with them.

It was to be expected that the uptake of ${ }^{15} \mathrm{~N}$ from ammonia would be slower with the protozoa than with the bacteria, and this has already been reported by other workers (Abe \& Kandatsu, I968) who carried out experiments somewhat similar to those described here. However, they used only 'single-shot' additions of ${ }^{15} \mathrm{~N}$ into the rumen and it is not possible to make accurate deductions from their results as to the extent to which the $\mathrm{NH}_{3}-\mathrm{N}$ was used as an intermediate in microbial protein synthesis. Their findings do, however, support the view that it may have been so used to a very considerable degree. It can be seen that larger differences occurred between the protozoal- $\mathrm{N}$ values than between the bacterial- $\mathrm{N}$ values on each of the diets. We have in the past noted wide variations in protozoal numbers even at short intervals on the same diet (Gray \& Pilgrim, 1953, unpublished). 
It will also be noted that absorption of $\mathrm{NH}_{3}-\mathrm{N}$ from the lucerne hay was greater than that recorded previously for this diet (Pilgrim et al. 1969). To what extent this could be attributed to differences in the batches of hay used is not known.

The procedures used here can be applied only to animals in which the rumen contents are in a steady state. Determination of total values for production of microbial- $\mathrm{N}$ would have to be based on a knowledge of the relative proportions of protozoal and bacterial-N, which is difficult to obtain. But calculation of minimal values based only on the extent to which the bacteria depend on ammonia for synthesis of their nitrogenous constituents may prove useful in further studies of the fate of dietary $\mathrm{N}$ in different natural feeds or in diets containing various $\mathrm{N}$ concentrates.

\section{REFERENCES}

Abe, M. \& Kandatsu, M. (1968). Arch. Tierernähr. 18, 247.

Borchers, R. (I967). F. Dairy Sci. 50, 242.

Bryant, M. P. \& Robinson, I. M. (1963). F. Dairy Sci. 46, I 50.

Duncan, C. W., Agrawala, I. P., Huffman, C. F. \& Luecke, R. W. (1953). F. Nutr. 49, 41.

Gray, F. V., Weller, R. A., Pilgrim, A. F. \& Jones, G. B. (1967). Aust. F. agric. Res. 18, 625.

Hydén, S. (1955). LantbrHögsk. Annlr 22, 139.

Loosli, J. K., Williams, H. H., Thomas, W. E., Ferris, F. H. \& Maynard, L. A. (1949). Science, N.Y. Iro, 144 .

Pilgrim, A. F., Gray, F. V. \& Belling, G. B. (1969). Br. ₹. Nutr. 23, 647.

Portugal, A. V. \& Sutherland, T. M. (1966). Nature, Lond. 209, 510.

Virtanen, A. I. (1966). Science, N.Y. 153, 1603.

Wallis, O. C. \& Coleman, G. S. (1967). J. gen. Microbiol. 49, $3^{\text {I } 5 .}$

Weller, R. A., Gray, F. V. \& Pilgrim, A. F. (1958). Br. F. Nutr. 12, 42 r.

Weller, R. A., Gray, F. V., Pilgrim, A. F. \& Jones, G. B. (1967). Aust. F. agric. Res. 18, 107.

Weller, R. A., Pilgrim, A. F. \& Gray, F. V. (1962). Br. J. Nutr. 16, 83. 